\title{
THE BEST SHEEPHERDER. THE RACIAL STEREOTYPE OF BASQUE IMMIGRANTS IN THE AMERICAN WEST BETWEEN THE END OF THE NINETEENTH AND THE BEGINNING OF THE TWENTIETH CENTURIES
}

\author{
THE BEST SHEEPHERDER. EL ESTEREOTIPO RACIAL \\ DE LOS INMIGRANTES VASCOS EN EL OESTE \\ NORTEAMERICANO ENTRE FINALES DEL SIGLO XIX \\ Y PRINCIPIOS DEL XX
}

\author{
Iker Saitua \\ University of California, Riverside and \\ University of the Basque Country (UPV/EHU)
}

orcid.org/0000-0002-8367-7070

Recibido el 15-12-2016 y aceptado el 12-7-2017

Resumen: El presente artículo estudia la imagen de los inmigrantes vascos en el Oeste norteamericano entre finales del siglo XIX y principios del Xx, y la influencia que esa imagen tuvo en la integración socioeconómica de este colectivo, dedicado fundamentalmente al pastoreo de ovejas, prestando especial atención al Estado de Nevada. Su objetivo principal es mostrar cómo dicha imagen fue racializada, cómo la etiqueta étnica de vasco fue equiparada a la categoría racial «blanca» en los Estados Unidos, especialmente tras la aprobación de la ley de inmigración de 1924, y cómo esta percepción benefició a los inmigrantes vascos, facilitando su integración. Para ello examina los estudios historiográficos, sociológicos y antropológicos sobre los inmigrantes vascos en el Oeste realizados a finales del siglo XIX y principios del siglo XX por intelectuales estadounidenses, y muestra cómo, influidos por el análisis turneriano y la ideología racialista de la época, elaboraron un estereotipo racial vasco, expresado en la imagen del «buen pastor», que terminó reflejándose en la prensa escrita estadounidense y divulgándose a través de ella. 
Palabras clave: Inmigración vasca a Estados Unidos, estereotipo vasco, imaginario racial blanco, raza y etnicidad, Oeste norteamericano, mano de obra agrícola.

\begin{abstract}
The present article explores the image of Basque immigrants in the American West between the end of the nineteenth and the beginning of the twentieth centuries, and how this image influenced on the integration process of this collectivity which was largely linked to sheep grazing, paying special attention to the state of Nevada. The main purpose of this article is to show how the ethnic label of Basques came to be equated with the racial category of «white» in the United States, specially after the passage of the immigration law of 1924, and how Basque immigrants entering the sheep industry benefited from these perceptions of a white identity. It examines the historical, sociological, and anthropological studies about the Basque immigrants in the American West of the late nineteenth and early twentieth centuries by American scholars, and it shows how these works, influenced by the turnerian notion and the contemporary racist ideology, established a racial stereotype about the Basques, embodied in the «best sheepherder» image, which finally was echoed by the American popular press.
\end{abstract}

Keywords: Basque Immigration in the United States, Basque Stereotype, Whiteness, Race and Ethnicity, American West, Agricultural Labor. 


\section{Introduction}

On June 20, 1937, the Oregonian published in its Sunday magazine a small photographic report about the Basque immigrants in southeastern Oregon, who were widely identified with the open-range sheep industry. Specifically, the article explained how the Basque immigrant community was highly concentrated in both Malheur and Harney counties, because their livelihoods depended on the sheep ranching economy in this corner of the American West. The Basque was, according to this article, «a friendly, hard-working race». The article continued: «In northeastern Spain, from the Bay of Biscay back into the Pyrenees mountains, is the homeland of this unique race. Since prehistoric times this has been their native heath. An intensely proud and independent people, whose origin is cloaked in mystery, theirs is a race apart». The words constituted the typical positive view of Basque immigration in the United States as the narrative had been developed during previous decades in the late nineteenth century when race classifications abounded. The article praised the Basque immigrants for their alleged industriousness in sheep grazing, warmhearted hospitability, and sense of pride in their origins. It also asserted that Basque immigrants assimilated easily into the dominant American culture. Although Basques were not Anglo-Saxon immigrants, the article said, «they are masters of English after but few years in this country». Moreover, it described Basques in physical terms, saying things like: «Many have blue and gray eyes, and could easily be taken for young Scandinavians». The underlying, or maybe, obvious message was that Basques were quickly becoming «Americanized»-according to the terminology used in the article - and even considered Caucasians, which is to say white Americans ${ }^{1}$. The Oregonian article indicated that by the late 1930s the Basques were well on their way to becoming an accepted, if not welcomed, ethnic group in the American West.

In the 1890s, as sheep ranching expanded rapidly in the western states, the Basque Country became an important source of pliable labor to work in the western public rangelands. At the turn of the century, although other ethnic groups also entered this occupation, Basques had become a noticeable and visible group in sheep grazing. During the early twentieth century, Basque immigrants' work as humble herders rose from

1 «Oregon's Basques», Oregonian, June 20, 1937, p. 10. 
a denigrated group of laborers to a respected position in the labor pool of the sheep industry. Anglo-European ranchers made the Basque «racially» distinct from other ethnic populations and admired their alleged high levels of skills in sheep grazing. Many western woolgrowers were convinced that Basque immigrant workers were superior sheepherders who supposedly possessed almost innate abilities to tend sheep on open and isolated ranges. Thus, Basque laborers acquired a reputation as highly skilled and «good» sheepherders, a perception that still persists today in the collective memory of the American West ${ }^{2}$. Their idealization of the skilled and successful Basque sheepherder presents the question of how this collectivity gained such an exalted reputation.

Considering Basque immigrant workers as better sheepherders than anyone else in the world is too simple. The story of Basque immigrant laborers as newcomers with particular skills for extensive sheep farming and their success in America is a more complex historical process. It has been obscured by a lack of conceptualization and concretization of the story of Basque sheepherding, as well as its mythical continuity in the historical narrative. Historian Kevin D. Hatfield has correctly said that «the absence of a concerted examination of the social, political, and economic evolution of Basque open-range sheepherding in the American West has allowed the romantic ideal of the nomadic Basque shepherd to remain entrenched in popular literature» ${ }^{3}$. In a similar revisionist vein, this article interrogates an element of the Basque immigrant experience in the West that has remained largely ignored: whiteness ${ }^{4}$.

The present article suggests that the racist ideology influenced the social construction of Basques as «good sheepherders», which strengthened and persisted in livestock agricultural circles in the American West. Some historians have argued that the racial integration of immigrants from southern and eastern Europe depended on the racial exclusion of others ${ }^{5}$. Furthermore, historian Richard White has said that «race», as compared

2 Saitua, 2016a, pp. 61-70.

3 Hatfield, 2003, p. 18.

${ }^{4}$ One of the most serious problems in recent labor historiography is, David R. Roediger has said, «the continuing tendency to romanticize members of the white working class by not posing the problem of why they came to consider themselves white and with what results». Roediger, 1991, p. 11.

5 Jacobson, 1998, p. 12. Other valuable sources include: Saxton, 1971; Barrera, 1979; Fields, 1982; Saxton, 1990; Roediger, 1991; Almaguer, 1994; Ignatiev, 1995; Allen, 1997. 
to ethnicity, class, and rural-urban fringe became the major element of division in the American West. White has noted: «Anglo Americans and white ethnic immigrants also used race as a way to insure their own privileged status in the social order» ${ }^{6}$. Drawing upon such historiographical models of race in American history as a social construct, this article offers a fresh interpretation of the way in which Basque immigrants were transformed into «whiteness» in the American West and, more particularly, in the state of Nevada. My point is that Basque immigrants became racially accepted laborers, if not prized laborers, resulting from their so-called racial characteristics and their «whiteness» in the first half of the twentieth century.

\section{The Basque Frontier of the American West: Historical Interpretations}

European immigrants have been largely ignored by the traditional and new western historiography. In the last years, however, scholars have begun a movement toward a more integrative study of European immigrants in the western history. If the new European immigration has been overlooked in the history of the West, this is especially true of the Basque immigrant community. As with many others, the traditional Turnerian frontier historiography has largely obscured immigrant groups other than to say that the frontier served to Americanize the immigrant. The Basques present a good example of an obscure group's amalgamation into the larger society as a result of the frontier process.

In 1893, Frederick Jackson Turner presented his thesis «The Significance of the Frontier in American History» to the American Historical Association in Chicago. Turner's influential ideas contended that the frontier process produced democratic institutions and assimilated all peoples. Turner suggested that in the process of westward expansion Euro-Americans on the frontier transformed themselves into a new homogeneous «American» character, infused with the spirit of ambition, innovation, and democracy. Turner wrote: «In the crucible of the frontier the immigrants were Americanized, liberated, and fused into a mixed race, English in neither nationality nor characteristics». Because of their frontier experience

6 White, 1991, p. 320. 
they left behind their Old World cultural traits and embraced an American democracy with innovation and self-reliance ${ }^{7}$. Contrary to this Turnerian view, other historians note that the frontier provided an escape and a space for the persistence of immigrant cultural traditions, suggesting that Turner simply ignored the immigrant in the frontier experience ${ }^{8}$.

Before Frederick Jackson Turner expounded his frontier thesis in Chicago, contemporary Theodore Roosevelt had finished his first two volumes of The Winning of the West (1889). In the first volume, the future president of the United States was more explicit in the interaction of «race» and environment of the western conquest. He looked at the «successful settlement» of the western territories by the Anglo-Saxon «race» and saw a different settlement pattern from most other major European colonial powers. Despite the interaction of groups from diverse European racial and ethnic backgrounds, Roosevelt argued that the «English-speaking race» prevailed and consolidated upon others and initiated a process of assimilation to the culture of the dominant Anglo-Saxon population. «Rival European races» and Indians, Roosevelt said, were accommodated to the dominant culture, but in the case of the Indians exclusion occurred ${ }^{9}$.

Theodore Roosevelt made a brief comparison between the expansion of the United States across the continent and the extension of the Roman Empire in the Mediterranean ${ }^{10}$. He noted that the Roman Empire occupied spaces where Bretons, Celts, and Basques lived and in many instances these groups retained their ancients' cultures adapting to the power and the innovation of the Romans. Roosevelt, however, like Turner, saw the power of the American experience (what Turner would have called frontier process) as an important force in the complete «Americanization» of the European immigrants beyond simply the pale of the «English-speaking peoples». Unlike the American experience, Roosevelt observed that in Europe and even Latin America in the face of European colonial expansion pockets of native cultures remained unassimilated. Roosevelt wrote: «Moreover, exactly as in Europe little ethnic islands of Breton and Basque stock have remained unaffected by the Romance flood, so in America there are

7 Turner, 1948, pp. 22-23.

${ }^{8}$ Luebke, 1990, p. 140.

9 Roosevelt, 1889, pp. 13-17.

10 More recently, some scholars have seen broad historical analogies between the Roman Empire and the rise of the United States to world power. See, for example: Johnson, 2004; Ferguson, 2004. 
large communities where the inhabitants keep unchanged the speech and the customs of their Indian forefathers». Roosevelt unexpectedly drew attention to the Basques as an ancient European unconquered «race» ${ }^{11}$. Frederick Jackson Turner read Roosevelt's work and reviewed The Winning of the West for The Dial magazine praising it highly ${ }^{12}$. In 1893, Turner declared the American frontier closed based on the census of 1890. In effect, Turner concluded that frontier expansion had been successfully completed confirming Roosevelt's interpretation of the victorious settlement of the Anglo-Saxon «race» across the American continent ${ }^{13}$.

Starting in the early twentieth century, initial scholarship on Basque immigration in the United States adopted the Turnerian vision that anticipated the «Americanization» of the Basque immigrant community. The Turnerian model influenced, either directly or indirectly, some of the early scholarly works on Basque immigration in the American West. This early scholarship tended to emphasize the rapid assimilation of Basque immigrants into the American mainstream. The central assumption of these pioneers' works was that Basque immigrants were expected to adapt their ways easily and quickly because of their «white racial» background. According to these early scholars, the Basque immigrant community did not need to get rid of all their ethnic traits. They could retain some of their cultural characteristics while adapting successfully to the core culture of the host society.

The traditional historiographical narrative has often argued that Basques were «racially» and culturally preadapted to sheep grazing conditions before arrival in the American West ${ }^{14}$. This originates with

11 Roosevelt, 1889, pp. 11-13.

12 Turner, 1889, pp. 71-73.

${ }^{13}$ Historian Frederick Luebke has pointed out that the Turnerian methodology not only assumed the dominance of environment on ethnicity, but also stimulates the study of ethnic groups in their intimate socio-economical relationships with the surrounding environment. Luebke has said that any immigrant group's history in the United States is the story of its particular assimilation into the Anglo-Saxon mainstream, based on the assumption that «assimilation is an interactive process in which the both the immigrant and the receiving societies are changed». In the assimilation process, Luebke has proposed the equation that «the greater the differences between immigrant and core cultures, the greater will be the potential for conflict». Luebke, 1990, pp. 143-144, 151, 152.

14 Some cultural geographers apply the concept of «preadaptation» to the transplantation and adjustment process by European colonizers from the Old to the New World. The success degree of European immigrants' settlement in America depended upon their strategy to select old economic systems and adopt new adaptive means in their new surroundings. Jordan and Kaups, 1989, p. 32. See also: Newton, 1974; Jordan, 1989. 
Pierre Lhande's 1910 book L'Emigration Basque (The Basque Emigration), which has served as a foundational text of the Basque diaspora scholarship. Although Lhande did not adopt Turner's frontier thesis, his analysis emphasized how Basque emigrants anywhere, under different conditions, were able to adapt easily to the local standards and become «good» citizens. Lhande related Basque emigration to features of the Basque society itself, with particular focus on the stem family structure with its inheritance system. While depicting a quasi-Malthusian ecological model, Lhande noted that the Basque Country offered agriculturally limited opportunities to a growing population. The result was emigration. Furthermore, he said that the emigration for Basques was a «racial» and cultural necessity. At that time, the concepts of race, people, and nation were commonly and loosely used. According to Lhande, the «atavistic anxiety» of the Basques was the main reason that explains their emigration. The «great driving force» of Basque emigration was the inherent «racial» trait to move out of their native country. The migratory movement, Lhande explained, was accelerated by other factors such as periods of economic or political crises. He wrote that Basques wherever they moved out of their homeland - to the American West or elsewhere - adapted easily, optimally, and quickly to the new environments. «Having faith in the vigor and strength of his race», Lhande wrote, Basques entered any occupation under any conditions, even those that were unfamiliar to them, like open-range sheepherding. He said that Basques were «racially», culturally, and psychologically ready to transfer to a new different way of life. Furthermore, he argued that Basques became successful immigrants wherever they settled due to their alleged physical stamina, perseverance, loyalty, idealism, and pragmatic spirit. His was a history of cultural nationalism and environmental determinism. The assertion of many of these qualities speaks of an ethnic or even racial essentialism ${ }^{15}$.

From the United States, some years later, Sol Silen in his La Historia de los Vascongados en el Oeste de los Estados Unidos (The History of the Basques in the American West) published in 1917 implicitly adopted the Turnerian notion of assimilation because of environmental influences experienced by immigrants in the West. Silen described Basques as a respectful, conservative, and proud «race». He noted that

15 Lhande, 1910, pp. 11-13, 22-23, 155, 157.

Historia Contemporánea 56: 81-119 
Basque immigrants had become important elements in the western sheep industry because of their «racial» characteristics and identity. He pointed out: «Their sterling honesty makes them to be eagerly sought by everybody and many of them, starting in very humble positions become partners of their former employers. Their deeply religious nature makes them men of very good morals, who establish themselves and raise families that are an honor to any country». To Silen, the main virtues of the Basque newcomers were friendliness, honesty, truthfulness, and loyalty. The immigrants' work herding sheep flocks in the desolate rangelands, far from the employers' supervision, according to Silen, was an example of their honesty to the sheep owner. This was something inherent of their «racial» type, which made it an «admirable race», Silen wrote. Paying tribute to the Basque-American community of the West, he went further saying that «the majority of the basques that belong to the fraternity of real men who through sacrifice, steady work, honesty and good moral principles are making of the western States the greatest emporium of America» ${ }^{16}$.

American intellectuals and the public sphere, generally, tended to define the Basque people inhabiting in the West in a racial and physical way. «Racial» depictions of the Basques mostly always implied a good judgment, which in turn would bring an inevitable idealization of the Basque sheepherders in the context of a mythicized frontier environment. In 1925, a master's thesis at the University of Southern California by Ione B. Harkness entitled «Certain Community Settlements of Oregon» reflected these ideas. In her sociological analysis, Harkness devoted one part of her investigation to the Basque immigrant community, which was in 1933 published separately as a small article under the title «Basque Settlement in Oregon». Harkness introduced the Basques as follows: «The Southeast corner of Oregon harbors one of the strangest and most interesting people of all her diverse races». Harkness erroneously contended that the topography and climate of the Basque Country and the Intermountain West were similar. Because of these conditions, Harkness said, the Basques were «adapted to their ancient occupation of sheep herding». Furthermore, Harkness stated that Basque immigrants «proved to be so much better herders than the Mexicans that the latter were quickly driven out». To Harkness, the Basque «race is extremely

${ }^{16}$ Silen, 1917 , pp. $5,6$. 
loyal and clannish». In addition, Basques, besides being «self-respecting» and «tireless workers», she wrote, «are very attractive in appearance and make a favorable impression on the sojourner among them». According to Harkness, these «racial» qualities of the Basques made them desirable to any western rancher whose livestock capital depended on the sheep laborers ${ }^{17}$.

In the late 1930s and 1940s, the sociologists Mary S. Wilcox, Joseph H. Gaiser, Flavia Maria McCullough, John B. Edlefsen, and Carol Maria Pagliarulo came to analyze the Basque immigrant social experience in the American West, with a special focus on their cultural transfer, social change, and adaptation in the new living environment ${ }^{18}$. The methodological preoccupations of those sociologists were primarily the assimilation process of the Basque community into the American mainstream culture. Above all, these scholars paid attention to the speedy «Americanization» of Basque immigrants. They contended that Basques accustomed themselves to the new environment, became an active social force, and integrated to host societies all around the American West. They spoke of the Basques' «complete amalgamation», as Mary S. Wilcox said, and suggested that those immigrants easily adapted and assimilated in America ${ }^{19}$. Joseph H. Gaiser, for his part, in talking about the Basques of Jordan Valley in Oregon, put the matter this way:

With the Basques the physical and cultural differences were not great enough to cause any lasting antipathy. Personality and character traits were of a congenial and solid type, the culture heritage of an independent, proud, and hard-working racial collectivity from the Basque provinces of the Old World ${ }^{20}$.

Applying the theory of the «race friendliness cycle» of the American sociologist Emory Bogardus, Gaiser said that Basques proceeded through assimilation, acculturation, and naturalization although «with some delay caused by isolation factors». According to those scholars, Basque immigrants' acculturation was a slow social process, due to their settlements in the less populated areas in the American West, which were their main

\footnotetext{
17 Harkness, 1925, pp. 42, 43, 45, 46. See also Harkness, 1933, pp. 273-275.

18 Wilcox, 1939; Gaiser, 1944; McCullough, 1945; Edlefsen, 1948; Pagliarulo, 1948.

19 Wilcox, 1939, p. 135.

20 Gaiser, 1944, p. 42.
} 
social spaces because of their principal occupation working with sheep in remote locations ${ }^{21}$.

In general, these scholars considered the Basque-American community successful immigrants and highly esteemed citizens. Although they conflated Basque people with a «race» and nurtured the late nineteenth century racialist theories that adhered to ideas of peculiar racial traits, some acknowledged that Basques arrived in America with a lack of background knowledge in sheep agriculture and that only, «accidentally», did they adapt to sheepherding. All of which made them more remarkable subjects ${ }^{22}$. Along the same line, John B. Edlefsen said «on the valley hillsides [of the Basque Country] a few sheep were grazed, but nowhere were there the vast herds which the Basque immigrants readily learned to manage as herders in the New World». The attitudes and values that those immigrants brought with them from the Old Country, along with ambition and willingness to work hard, according to Edlefsen, were transmitted to their new work in the sheep industry. In addition, he stated, the good reputation that the earliest immigrants gained in the sheep business made easier the contracting and hiring of subsequent newcomers. In Edlefsen's words: «The satisfactory work performance of the first few resulted in an economic welcome being extended to others of this unusual immigrant group from the Pyrenees region in Spain ${ }^{23}$.

The 1960s and 1970s witnessed a new wave of Basque studies on immigration in the Far West consisting of dissertations, articles, and even one monograph. In a similar manner as the previous scholarship did, these new scholars tended to focus on the social assimilation of the Basque immigrant community into the American cultural mainstream. In 1968, for example, Grant E. McCall concluded his dissertation by acknowledging the successful Basque «adaptation» in the American West $^{24}$. In addition, the new scholarship began to pay increasingly at-

${ }^{21}$ Gaiser, 1944, p. 42. Emory Bogardus suggested the following seven stages in the immigrants' integration process: first, friendly interest for the newcomers; second, economic welcome and immigrants entered the labor market; third, immigrants are unwelcome and seen as a social menace; forth, legislative opposition; fifth, social integration movements; sixth, sympathy and acceptance of immigrants; and seventh, challenges of the second generation. Bogardus, 1930, pp. 612-617.

22 Gaiser, 1944, p. 80.

${ }^{23}$ Edlefsen, 1948, pp. 51-53, 60-61, 136.

24 McCall, 1968, p. 115. 
tention to Basque immigrant interaction with the social and physical environments in the West. Their efforts took them to the different aspects of the Basque immigrant experience that emphasized the cultural dimension and effects of isolation in the mountainous environment of the sheep industry ${ }^{25}$. In 1970, Joseph R. Castelli in his comparative study, Basques in the Western United States, analyzed the factors affecting the establishment of the Basque immigrant community, the interplay of the two cultures - Anglo-American and Basque-, and the development of the «cultural landscape» created and modified by both social forces. Basques' land ownership and sheep herding were powerful elements in the legitimization of this ethnic group in the American West. He wrote: «The common economic system of the Basques, sheep raising, not only gave them identity but assisted in perpetuating their culture» ${ }^{26}$.

At the same time, Wilbur Shepperson in his Restless Strangers: Nevada's Immigrants and Their Interpreters (1970) observed how Nevada's history and culture revealed a special preoccupation with the foreign newcomer. Shepperson argued that immigrant groups - such as Basques - found opportunities to prosper in Nevada's marginal unclaimed and unpopulated lands, and played a crucial role in the state's formation, settlement, and development. In the late nineteenth and early twentieth centuries, nonetheless, they suffered from traditional discrimination and marginalization from Anglo- and northern European stock. As the author demonstrated, anti-immigrant views were being echoed by the press and some contemporary literature. The negative stereotypes of Basque immigrants - such as «dirty Basco»- developed in fiction and existed for years ${ }^{27}$. With little context and historical analysis, Shepperson explained how Basque immigrants eventually gained a reputation of respect and drew considerable public attention in Nevada. He wrote: «Nevada's immigrants were always more than a silent minority, an ill-trained peasantry, or an intellectual mediocrity... Scores of the foreign-born were able to find a personal meaning in Nevada and to translate their inheritance into a new perspective» ${ }^{28}$. Despite this claim, 1967.

${ }_{25}$ Sather, 1961; Ruiz, 1964; Kelly, 1967; McCall, 1968. See also: Gómez-Ibáñez,

${ }^{26}$ Castelli, 1970, pp. 129-141, 153.

27 Shepperson, 1970, pp. 58-59.

28 Ibid., p. 41. 
Shepperson's argument that Nevada provided immigrants with some opportunities for advancement both reflects and perpetuates Turner's frontier thesis.

In 1975, anthropologist William A. Douglass, in his Amerikanuak: Basques in the New World (coauthored with Jon Bilbao), analyzed how the Basques became the backbone of the western sheep industry. Douglass pointed out that the Basque people «more than any other ethnic group... have affected the history and development of America's open-range sheep industry» ${ }^{29}$. In realizing the American Dream, Douglass still tended to place emphasis on the Basques' «successful» assimilation into the American way of life, although he contended that they did not discard all their ethnic marks or reshape their identity in their continuous symbiotic relationship with the Anglo-core population. According to Douglass, Basque immigrants could pass unnoticed and eventually assimilate into the mainstream Anglo-American culture because they were not much different from the dominant Anglo-European population. He wrote:

The fact that Basques are Caucasians protected them from being made targets of racial discrimination. Because they did not cause a «social problem», they have not attracted as much attention in American society as have other immigrant groups. The value orientations of Basque immigrants did not contrast at all with highly esteemed values in American culture, such as dedication to work, thrift, and hygiene. In this respect, Basques were as «American» as any other immigrant group, possibly more so than most. Consequently, no major conflict in values that might have placed the Basques in the public spotlight has characterized relations between them and the wider society ${ }^{30}$.

Douglass identified the Basque immigrant population in the American West as Caucasian and took for granted the privileges bestowed to them under this «racial» category in the United States. Previously, he had written: «The fact that the Basques are Caucasians meant that they did not possess physical clues which would make them readily identifiable by the uniformed and hence easy marks for discrimination on

${ }^{29}$ Douglass and Bilbao, 1975, p. 325.

30 Ibid., p. 3. 
racist grounds» ${ }^{31}$. The question here is not, however, whether Basques were Caucasians or not, but who and why categorize Basques as Caucasians. Historian Matthew F. Jacobson has stated: «Caucasians are not born... they are somehow made. It's just a question of who does the making» ${ }^{32}$.

In 1991, historian Richard W. Etulain edited his anthology Basques of the Pacific Northwest in which he put the Basque immigrant experience into a broader social context. Etulain explained that the dominant image of the first-generation Basque immigrants was that of being sojourners who intended to stay in the United States only temporarily to make enough money and return home. Etulain discussed the tensions between the Basque-immigrant community and the dominant host society. It can be inferred from Etulain's book that in the late nineteenth and early twentieth centuries both negative and positive images toward Basque immigrants coexisted depending on the specific issues at stake. It can also be concluded from his work that as some early Basque immigrants became prominent ranchers and second-generation BasqueAmericans assimilated into American mainstream, Basques gradually obtained a good reputation among their neighbors in the different local communities in the West ${ }^{33}$.

Etulain's work offered a new perspective and opened new avenues for understanding the Basque immigrant experience in the American West. After him, other experts on Basque immigration in the United States - such as Jeronima Echeverria, John Bieter, or Kevin D. Hatfield - have also adopted a revisionist view ${ }^{34}$. But none of them have interrogated how Basque immigrants benefited from the general climate of white supremacist opinion in the United States. As the following pages illustrate, although at first Basques were subjected to overt ethnic and «racial» discrimination, the positive image of the Basques as «good sheepherders» ultimately prevailed, which resulted largely from their whiteness.

31 Douglass, 1970, p. 16.

32 Jacobson, 1998, p. 3.

33 Etulain, 1991, pp. 7, 20, 80-90.

34 Echeverria, 1999; Bieter and Bieter, 2000; Hatfield, 2003. 


\section{Basque immigrant labor in the open-range sheep industry of the American West}

In the 1850s, the Gold Rush in California brought some Basque families to the American West ${ }^{35}$. They arrived primarily from the provinces of the northern Basque Country and Latin America, particularly from Argentina. Typically, those early Basques fled to South America during the Spain's First Carlist War (1833-1839). After the late 1848 public announcement of the California gold discovery, Basques living in South America rushed to California to try their luck. Some poured their work and capital from mining efforts into the livestock business. Others started their own business ventures in livestock ranching from the beginning, applying the lessons learned during their years in South America. In the 1850s, California and its major metropolis, San Francisco, became the economic center of the Far West for many businessmen, traders, stockmen, and overall capitalist investors. Although it is difficult to determine how many Basques came to California in those years, by the early 1860s they became an influential group in San Francisco and the Central Valley. They ran primarily livestock ranch operations and other business ventures related to stock agriculture. All the Basque pioneering families emphasized mutual help to promote the welfare of their community. In the context of the rapid commercial and industrial expansion in California, these families amassed large holdings and became landowners by purchasing government land, and using their workers, friends, and family members as strawmen to purchase other extensive land parcels. The main goal was always to maximize profits and holdings in both land and stock ${ }^{36}$.

By the 1860 s, California land prices and population increased pushing stock operations more and more into marginal lands. The completion of the Transcontinental railroad made it feasible to use distant marginal

35 The Basque presence in the North American West dates back to the Spanish colonial period in the American Southwest. Between the late sixteenth and early nineteenth centuries, Basques were directly involved in the Spanish Empire's expansion from colonial Mexico into territory north of the Rio Grande. The sustained inflow of Basque immigrants into the Far West, however, took place in the mid-nineteenth century during and after the California Gold Rush. For a detailed exposition on the earliest Basque presence in the American West, see: Douglass and Bilbao, 1975; Simmons, 1991; Garate, 1993, 1998, 2005; Azcona Pastor, 2004. See also: Weber, 1992; Goodman, 1997; Kessell, 2002.

36 Douglass and Bilbao, 1975, pp. 203-233. 
rangelands and to send the stock and wool to markets both to the West and to the East. The lands of faraway Nevada were examples of marginal lands now open for development and exploitation. The available public domain attracted many stock operators to Nevada. After 1859 , the development of the Comstock Lode stimulated the expansion of livestock ranching in the Great Basin. During the 1860s and 1870s, some livestock operators including Texas interests saw the grazing potential of northeastern Nevada. Among these early livestock operations were the ranches built by Basques. By the 1860s, Nevada increasingly became the rural hinterland for western and eastern economic centers ${ }^{37}$.

The early presence of Basque-owned ranches provided many of the foundations of the Basque immigration pattern into the intermountain West. They provided the foundation for community attachment and solidarity. Although the Basque pioneering families did not constitute the first permanent settlement in Nevada, their economic ventures determined subsequent Basque migration and settlement in Nevada. Not surprisingly, the early Basque ranch operations served as the immigration conduit between the Basque Country and the American West providing the first centers of employment for Basque workers. After 1869, the transcontinental railroad offered connections to the East Coast and facilitated Basque immigration to the Far West ${ }^{38}$.

The expansion of sheep agriculture in the 1890s brought the employment of significant numbers of workers, largely European immigrants, to labor in the most desolate rangelands of the Great Basin. During the 1890s, there was demand for contract labor from sheep operations, some of which were owned by Basques. Early Basque pioneer stock operators began recruiting Basque workers from the Old World. The efforts of these early contractors set the immigration pattern between the Basque Country and the American West. Young male workers, typically single, provided the ideal workforce for sheepherding over extensive ranges. Possessing few skills beyond whatever experience they had acquired on their small family farmsteads, these men were most often recruited through informal channels from rural areas in the Basque Country. For instance, private personal letters from immigrants urged and encouraged family members and friends to immigrate and work as sheepherders. These men entered the industry hav-

\footnotetext{
37 Young and Sparks, 1985, pp. 71-72; Townley, 1998, pp. 1-9.

38 Bieter and Bieter, 2000, p. 28.
} 
ing little knowledge of or familiarity with sheep. In the Basque Country, some families owned only a few cattle and sheep, a situation that sharply contrasted with that of the western ranges where bands of thousands of animals grazed on vast public rangelands ${ }^{39}$.

The reasons behind emigration vary depending on each individual ${ }^{40}$. Most emigrated for economic reasons. Like other European immigrants, many Basques were unable to support themselves economically in their homeland, particularly after the Second Carlist War (1872-1876). The western American sheep industry offered something of a safety valve for those affected by the upheaval. While it did not promise great wealth, life as a sheep herder in the American West attracted many Basque immigrants with few other opportunities at home, and news of some successful individuals encouraged more young men to make the journey. The traditional Basque family structure itself also produced emigration. In the Basque Country, the custom of primogeniture meant that the eldest son inherited the family estate. While this system allowed family lands and the name to be perpetuated, it also denied other children, both male and female, titles and land ownership. As such, children other than the firstborn faced limited choices. Men could work for another house, join the priesthood, or enlist in the army. Women hoped to marry the heirs of other farmsteads. Over time, however, increasing numbers of Basque men without the prospect of inheritance in the old country decided to emigrate to America ${ }^{41}$.

Widely considered the lowest-ranking occupation in the sheep industry, sheepherders were contract laborers, employed by either oral or written agreement, whose main duty was to care for and oversee the fattening of range sheep to be marketed for wool and meat. Because of the arid and semi-arid conditions, handling sheep on the western range required grazing flocks of nearly two thousand head over great distances, constantly moving from one pasture to another depending on the season. Basque men found employment as sheepherders largely because the work did not require special skills or command of the English language. Sheep work was considered by the American public a tedious, tiring, and un-

39 Echeverria, 1999, pp. 27-31; Douglass, 1970, p. 19.

40 A study of the causes that pushed Basques out of their country, particularly those from Gipuzkoa, is Pildain, 1984. A collection of articles that examine the Basque emigration to America, particularly to Latin America, is Angulo Morales and Álvarez Gila, 2002. See also Azcona Pastor, 2004.

${ }^{41}$ Douglass and Bilbao, 1975, pp. 123-137. 
desirable job. Thus, Basque immigrants found their largest opportunities in this low-paying job. Basque sheepmen were pleased to employ other countrymen as sheepherders. Non-Basque sheep operators, for their part, found Basque immigrants acceptably productive workers and mistakenly assumed they were applying the skills acquired back in their home country ${ }^{42}$. Then, Basques were socially constructed as good herders who had distinct and innate racial characteristics.

\section{4. «The Brave Basque»: Racialized Views of the Basques in the United States}

At the same time that Basque immigrants entered the western sheep industry in the late nineteenth century, several European anthropologists went to the Basque Country with the intention to learn more about this land and to collect information about its inhabitants. Their publications portrayed Basques as an ancient and anomalous race distinct from any Indo-European people. In other words, these writings perpetuated a racialized image of the Basque ${ }^{43}$. At that time, race meant both physical attributes (for example, skull shape and size) and socio-cultural traits. While there was a wide range of speculation about Basques and their origins, the new scholarship produced a rather idealized image of the Basque. These ethno-racial hypothesizes did not answer questions on the origins of the Basques. The origin mystery added to the image of the romanticized Basque $^{44}$. Such anthropological studies ultimately attracted the curiosity and the interest of the dominant society in the American West paving the way for the acceptance and integration of the Basques.

By the 1870s, the word «Basque» started appearing frequently in the American newspapers. Articles even echoed the contemporary anthropological interpretations about the Basques ${ }^{45}$. In 1875, the New York Times

42 Saitua, 2016a, pp. 66, 69-70.

43 This study applies the concept «racialized» following the work of sociologists Michael Omi and Howard Winant. They define racialization as «the extension of racial meaning to a previously racially unclassified relationship, social practice, or group». Omi and Winant, 1994, p. 111.

${ }^{44}$ Rua, 1990, pp. 200-201; Azcona Mauleon, 1982, pp. 754-773; Ripley, 1899, pp. 180-204.

45 For example: «Fossil Human Races», New York Times, April 28, 1874, p. 12; «Scenes in Spain», New York Times, January 10, 1875, p. 2. 
published a report on the ethnographical observations of a special correspondent who went to Hendaye (Labourd) in the northern Basque Country to learn more about the Basque culture. The author found a curious mixture of festivals and Catholic religious life in the Basque Country. In addition, the American traveler noted a distractive Basque racial identity and attractiveness in physical appearance: «The type of the Basque race, both male and female, is not molded on a large scale, but the women, although petite, are well proportioned, and if not positively handsome, they are, at least, healthy-looking, and have not that sallow complexion which is characteristic of the male sex through Spain ${ }^{46}$.

In the summer of 1878, a correspondent of the Cleveland Leader traveled to the Basque Country to learn more about the local people. To him, everything was enchantment and exotic. He introduced the Basque in the following manner: "At this stage of my journey there seemed no fear that I should lack for food or shelter. I was fairly [sic.] in the Basque country, and knew that this people were among the most hospitable of races». Travel through the Basque Country peeked the curiosity of this reporter about the local people and this led him to further questions about this «strange race». His view of the Basque racial type was based on both physical qualities and behavioral traits. «As my attention fastened itself upon their frank healthy faces, and lithe, muscular frames - each, according to his years, being a type of manly beauty and symmetry-», this correspondent wrote, «I was struck with admiration for the race from which they spring»:

Reflecting that for ages past the sires of these men had been dwellers in the same region, I first began to realize how a people of such unspoiled vigor, jealous of its liberties, its integrity, and traditions, could continue unsubdued through the long centuries, thwarting every effort of Carthaginians and Romans, Goths and Saracens, French and Spaniards, to efface their identity, or entirely dominate their freedom... Other mountain races have shown valor and love of freedom, and one after another have become merged into the most powerful nationalities of the plains; but here is one whose origin is lost in the night of antiquity, still holding to its native fastnesses, intact in its usages and language, and absolutely uncorrupted in its tribal identity ${ }^{47}$.

\footnotetext{
46 «A Basque Holiday», New York Times, February 15, 1875, p. 10.

47 «The Basque People», New York Times, August 21, 1878, p. 3.
} 
This reporter acknowledged a distinctive racial identity. He put together the alleged Basques' natural qualities and temperamental attitudes, especially: valor, hospitality, goodness, kindness, determination, trustworthiness, integrity, sovereignty, fastness, and purity ${ }^{48}$.

By the 1880 s, public opinion commonly cast Basques as an exceptional race. In 1882, the New York Times published an article on the Basque fishermen and their longtime connection to the sea since the days of fishing and hunting of whales. The article used «brave, honest, and industrious», as the main adjectives in describing the Basque people, «while both men and women are always cheerful and light-hearted». The text described the importance of the fishing industry for the Basques, by saying that «they belong to a people who, for centuries, have repelled foreign invasion, have enjoyed free institutions, and made their own laws. The Basque fishermen are the descendants of the old whalers, and retain their traditions» ${ }^{49}$.

In the 1890s, testimonies about the Basque people continued to appear in American newspapers. In 1893, the New York Times reprinted a small article from the London Globe on the uncertainty about the origins of the Basque language. It read: «Basque Is a Lonely Tongue Still». On June of 1896, the New York Times reprinted an article from The Gentleman's Magazine, which asked a persistent question, «Who Were the Basques?» Echoing the theories of contemporary scholars, the physical anthropologist Paul Broca noted that the Basque crania were distinguished from the African and European type. Just two months later, in the same newspaper an article took up the subjects of the Basques during the advance of the Roman Empire into Western Europe and the strategic position that the Basque Country occupied and its importance to Rome. The Basque had the reputation of standing as «a rock against Roman and all succeeding waves [of conquest]». This idea was common among many American interpreters who considered Basques the «Warders of the Pyrenees» ${ }^{50}$. At this point, they reproduced an image that had been built by the political elites of the Basque Country decades before, as historian Coro Rubio has explained ${ }^{51}$.

48 Ibid.

49 «The Early European Whalers», New York Times, March 19, 1882, p. 12.

50 «Basque is a Lonely Tongue Still», New York Times, October 8, 1893, p. 17; «Who Were the Basques?», New York Times, June 28, 1896, p. 26; «To Follow a Roman Road», New York Times, August 28, 1896, p. 13; «The Basque Provinces», New York Times, September 3, 1899, p. 12 .

51 Rubio, 2016. 
In 1898, at the time of the Spanish-American War, while United States and Spain were negotiating peace, an American newspaper published a favorable notice about the Basques. The title itself speaks positively of the Basques: "Valiant Vizcayans: Spaniards Who Are Always Against the Government». The author wrote: «Like the Bretons in France, the Welsh, the highland Scotch, they [Basques] have been overrun, but never overcome» ${ }^{52}$. The article described generally how the Basques from the province of Biscay fought in the Second Carlist War to defend and protect their fueros, a set of norms and customary rules that governed community life in each of the Basque provinces, regulated the relations of these territories with the Spanish Monarchy, and at the same time guaranteed the status of the local elites until 1876. Along with the Catholic faith, the fuero was one of the most important component of the nineteenth century Basque identity ${ }^{53}$. Furthermore, according to historian Coro Rubio, in the late nineteenth century Basques forged a singular identity to differentiate themselves from the rest of Spain. Rubio suggests that a Basque elite invoked this exceptionalism to secure their political status and economic freedom $^{54}$. In the same vein as Coro Rubio's work, I further suggest that American public opinion reinforced this belief which made Basques socio-culturally, politically, and racially exceptional in the United States. As such ideas gained currency in the United States, they contributed to a high regard for the Basque immigrant sheepherders in the American West ${ }^{55}$.

Furthermore, the article contended that the Basques were good warriors because they learned how to adapt to their environment: «These mountains are the natural habitat of the Basques, and whenever an insurrection breaks out the inhabitants remove to the mountain fastnesses and can indefinitely prolong the war against any force brought to bear upon them». The Basques, it concluded, «are mountaineers, and mountaineers in every country are independent, liberty loving and impatient of any form of political control save when exercised by their own people». Furthermore, «they have never patiently submitted to a foreign yoke». The article included a cartoon showing an alleged «Vizcayan warrior» in a Basque village, holding a shotgun and wearing what it supposed to be traditional

52 «Valiant Vizcayans», Daily Ledger, August 11, 1898.

${ }^{53}$ Rubio Pobes, 2003, p. 99. On this Basque juridical system in the nineteenth century, the following works by historian Coro Rubio Pobes are important: 1996; 1997.

${ }^{54}$ Rubio, 2016, pp. 417-418. See also her monograph (2003).

55 Saitua, 2016b, p. 348. 
Basque clothing. Rather than a Basque native soldier, this drawing suggested an image of a Moorish warrior of Northern Africa, with the classic turban and baggy wear. The Orientalized image unwittingly displayed the Basques as members of a Mediterranean race. An American reader of the time could see Basques belonging to one of the darker peoples of southern Europe. His darkened face made him strange and angry, but at the same time it portrayed a fierce protector of his homeland ${ }^{56}$. Although the article is talking about the Basques from the province of Biscay, the reader might understand that the author was actually thinking in terms of all the Basque provinces (see Figure 1).

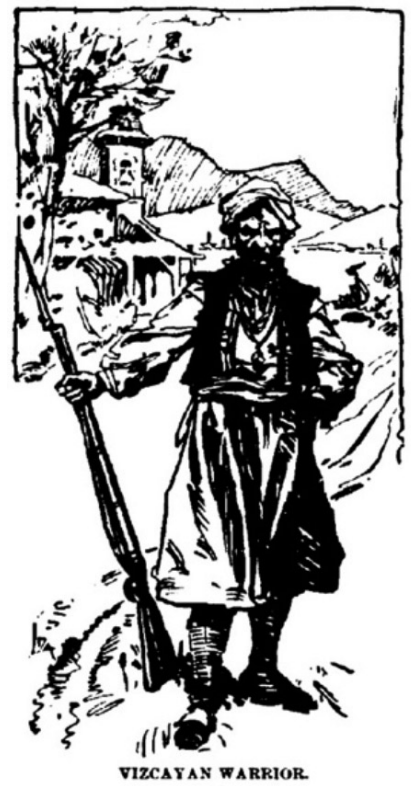

Figure 1

Cartoon «Vizcayan Warrior»

Source: Daily Ledger, August 11, 1898.

56 Daily Ledger, August 11, 1898. 
Clearly many newspapers were covering stories about Basques at the same time that a Basque sheepherder population was appearing in the Far West. Generally, newspapers depicted Basques superficially with a standardized version about Basques and their identity. On August 3, 1899, an article in a Nevada newspaper appeared with the following descriptive title: «The Brave Basque». According to this text, Basques were «proud and unconquered people». The article further stressed: «They [Basques] are entirely different from the Spaniards south of them, and indeed they can be classed with no other race of the earth... Only in this tiny country, among the mountains have these sturdy, stalwart people succeeded in retaining anything of their own individuality... ${ }^{57}$. In positive terms, the text went on to describe the Basque language, political system and country's natural resources. All in all, the writer contended that Basques were of a different racial stock than the rest of Spain. As writers continued to depict the Basque as noble survivors of long centuries of struggle, the strength of the Basque character emerged.

These positive stereotypical images persisted well into the twentieth century in articles about the Basque immigrant sheepherders in the American West. On December 14, 1901, an American journalist wrote, «the best sheepherder in the world is the Basque». The text speculated that only Basques were psychologically capable to confront the isolation demanded of sheepherders in the most remote rangelands of the American West:

No matter how strong the man may be at the start, if he will follow sheep long enough he will wind up a driveling idiot. No man has ever been able to explain why this is, but it is a fact, nevertheless. I have known young, healthy Mexicans and Americans to begin herding sheep, and in less than five years their brains had given way and they could not talk coherently. Perhaps there is something in the theory which is sometimes advanced that constant association with the sheep reduces their intellectual capacity to the level of their associates, or perhaps there is something in the theory that the loneliness and the solitude of the calling will wear away the brain tissue of any $\operatorname{man}^{58}$.

57 «The Brave Basque», The News, August 3, 1899, p. 2.

58 «Sheepherders Go Insane», Des Moines Daily News, December 14, 1901, p. 4. 
In working with the sheep, according to this article, Basques were better able to stand the loneliness and «the strain than other nationalities», and next to him in endurance were the Mexicans. Both, stated the text, «can stand following the sheep for years, but both will succumb in time. An American [can] hardly stand the strain for a year, and I have know[n] some of them who did not stand it that long». In closing the article claimed: «There are thousands of insane Mexicans on the border today who became so by reason of their occupation as sheepherders and for no other ${ }^{59}$. The essentialist view that attributed to Basques special sheepherding skills, as we will see later, also conferred upon them a degree of racial whiteness and values that entitled them to a privileged labor category.

\section{From «Dark-Faced Strangers» to White Subjects: Basque immigrants and their new racial identity}

The increasing presence of Basque sheepherders in the public ranges also drew derision amidst a cowboy culture in the West. Basque sheepherders with their huge bands of sheep coming on to public grazing lands were perceived as a serious economic and environmental threat by local ranch owners, small town business communities and the emerging Conservation Movement. By that time, nomadic sheepherders and Basque immigrants were synonymous. In 1899, the influential California Cultivator and Livestock and Dairy Journal contended: «...the sheepmen of the Sierra Nevada are for the most part a lot of irresponsible Basques, who own no other property than their sheep; they pay no taxes, evading them by moving ${ }^{60}$. This rural public sentiment against the itinerant sheep grazing on the federal lands was in accord with the yeoman farmer private property tenants of Jeffersonian Democracy that the privatization of small farms of much of the public domain made possible ${ }^{61}$.

In the late nineteenth century exploitation and degradation of the natural resources raised concerns among forestry and water experts as well as those Progressives who saw opportunities to champion the causes of an emerging Conservation Movement. This movement advocated the protec-

\footnotetext{
59 Ibid.

${ }^{60}$ California Cultivator and Livestock and Dairy Journal, 13 (1899), p. 97.

${ }^{61}$ Rowley, 1985, p. 44; Foss, 1960, pp. 12-13.
} 
tion of forest lands in the West and emphasized «wise use» of resources on those lands based upon a utilitarian doctrine that stressed use for the greatest number, for the greatest good, for the longest period of time. In February 1905, the Department of Interior's administrative functions and responsibilities were transferred to a newly established agency, United States Forest Service, within the Department of Agriculture. The Forest Service issued a Use Book which set out rules on grazing seasons, set numbers of stock, and issued grazing permits based upon property ownership and traditional use criteria. Three classes of grazing permits were available: first, Class A to those owners of ranch properties within or adjacent to the National Forests who customarily grazed stock on lands now within the National Forests; second, Class B for those who possessed property near the National Forests and traditionally grazed stock in these high mountain pastures; and third, Class $\mathrm{C}$ to itinerant graziers who did not own property or a home ranch. The various permits were issued on the basis of this preference criteria. All permits granted were considered grazing privileges not rights by the Forest Service. The preference system favored the first two classes and generally excluded the third or Class $\mathrm{C}$ permits. Forest Service considered these policies the mechanism to defend established landowning ranchers and small homesteads against the intrusion of itinerant sheep graziers. At that time, despite a handful of Basques were already landowners, others continued grazing sheep on the publicdomain lands owning no land and, therefore, receiving Class $C$ permits ${ }^{62}$.

After 1905, when the U.S. Forest Service began establishing a range control program in newly created National Forests, the sheep industry's transhumant or migratory use of grazing resources on the public domain and the foreign character of its Basque workers attracted more attention from policymakers and public opinion. American literature made Basques increasingly popular as outsiders nomadic sheepherders in stories about grazing conflicts and pasturage problems ${ }^{63}$. In her 1906 novel, The Flock, Mary Austin, while describing sheepherders' experiences in California's Sierra Nevada, wrote that «...the actual management of a flock on the range is never a "white man's job"», but French, Portuguese, Mexican, and Basque immigrants'. Austin understood that these

62 Rowley, 1984,pp. 61-67; Rowley, 1985, pp. 4, 5, 46-62.

63 In 1894, preservationist John Muir had stigmatized sheepherders and made them responsible for overgrazing in California's Sierra Nevada. Muir, 1894. On this issue see also: Snyder, 2003. 
immigrants who brought with them their cultural traditions and ways of life were socio-culturally preadapted to sheep herding in the West ${ }^{64}$. Contrary to this assumption, Basque immigrants were not preadapted and qualified for extensive sheep grazing, but like many others had to learn and adjust to this new job in the American West. These collectivities considered non-white (including the Basques) were marginal people who were unable to find better employment and accepted this low-paying work readily ${ }^{65}$.

The widely held image of the Basque as a wandering landless sheepherder on the margins of the grazing economy gave the entire Basque immigrant community a somewhat blackened and negative reputation. On April 7, 1907, an article appeared in the Washington Post describing the «arduous» life of the Basque sheepherder out on the range. On the matter of race, it depicted Basque immigrant sheepherders as being a non-white race. The article began as follows:

City wanderers in the mountain meadows of the California Sierras occasionally meet silent, dark visaged men who follow herds of sheep alone with their dogs. As the stranger rounds some sudden corner in the dusty highway the sheep, blocking the road divide and hurry by his buckboard. Then back in the dust of their hoofs the stranger sees the shepherd. The ragged man with the staff and the mongrel collie at his heels may raise his stick in mute salutation as he passes; he may slouch by without a word, though there be no other human being within thirty miles of the spot. A minute and he is lost in the wilderness around the turn of the road.

This man is a Basque shepherd, one of the strange exiles from the Pyrenees who find a new home in the California mountains. He is content to live alone with his flocks and his dogs four months out of the year up in the cool meadows of the mountains, setting no man save the casual traveler. In the wintertime when the sheep are on the valley ranges he loses himself somewhere in the shoddy valley towns along the Sacramento, not to reappear until the summer wind shrivels up the valley grass and sends the sheep back to the mountains.

There must be a hundred of these dark-faced strangers from Spain who lead the sheep through the Sierra range from Shasta down to Kings

\footnotetext{
64 Austin, 1906, p. 62.

65 Saitua, 2016b, pp. 348-349.
} 
River. The valley folk call them gypsies in their ignorance. They are considered shiftless, roving fellows. Because they do not care to talk or to mingle with «white men» they are looked upon with suspicion. Yet everybody concedes that they are good shepherds. No other man would work all summer alone for so little pay ${ }^{66}$.

The article continued explaining the seasonal migration of the transhumant sheepherders between lowland winter and upland summer pastures. It also pointed out that the loneliness in the rangelands invoked alienation and sometimes despair in these immigrants ${ }^{67}$.

By the turn of the century, although Basques assumed the status of a curious race that was brave and independent, they were oftentimes discriminated against. The negative conception of the Basque immigrants in the American West as nomadic and tramp sheepherders persisted with some cattle owners continuously using the image as a pretext to discredit and even demonize the sheep industry. Pejoratively they could be called «Black Bascos», «Greasers», or «Garlic Snappers» ${ }^{68}$. Basque foreign cultural traditions helped make their presence a target of suspicion and criticism during the period leading up to World War I when an American xenophobic movement was on the rise. In this context, Richard Etulain has said, «they were pictured as foreigners, as mainly sheepherders, and cultural parasites» ${ }^{69}$.

During the 1910s, furthermore, Nevada's U.S. Senator Key Pittman launched a campaign against the open-range sheep industry in the Great Basin responding to his cattle constituency. Basque workers became the focus of Pittman's attacks. He blamed Basque sheepherders for depleting public ranges. Pittman denigrated the Basque immigrant labor as inferior and despicable. He blamed Basques for being an economic threat to $\mathrm{Ne}-$ vada because they took these agricultural jobs and depressed local wages. Pittman's anti-immigrant sentiments fitted well with his fight against the sheep industry that was synonymous with the Basque immigrant community. Pittman's stand against the Basque-run sheep industry did not gain the expected support in Nevada, and in fact there was a backlash that

66 «Exiled Basques in California Go Mad Tending Their Flocks», Washington Post, April 7, 1907, p. 9.

67 Ibid.

${ }^{68}$ Bieter and Bieter, 2000, p. 156; Powers, p. 249; Drago, 1924, p. 21; Echeverria, 1999, p. 32. See also: Shepperson, 1970.

69 Etulain, 1977, p. 8. 
came to the defense of the Basques as an important community contributing to the economy of Nevada. In time a popular sympathy developed towards Basque immigrant labor in Nevada ${ }^{70}$.

During the first two decades of the twentieth century, as Basque immigrants shifted to a more settled community, Richard Lane has noted, «their position was no longer compromised by the "tramps" and they seem to have enjoyed greater acceptance as hardworking people who meant to stay in the community» ${ }^{71}$. On March 29, 1911, the Reno Evening Gazette published an article with the headline: «Desirable Immigrants». It noted approvingly that the Basque population in Nevada was «increasing year by year until they now form no inconsiderable proportion of the inhabitants of the state». The Reno Gazette attributed Basques' labor in the western open-range sheep grazing to the immigrants' rural lifestyle and pastoral occupation in their home country. In terms of a classical American self-made ideology, the article praised Basque immigrants and accorded them a respected and honored position within the broader society because they had built up wealth through their labor in the sheep industry. Then, the Gazette argued that Basque immigrants were eagerly adapting themselves and assimilated quickly into mainstream American culture: «It is always their ambition to become naturalized as quickly as possible and, being a people opposed to race suicide, they marry early in life and rear large families... The second generation of Basques... are most thoroughly Americanized and become perfectly assimilable». The article further praised the Basque immigrant community of Nevada as respectable and good citizens. In the Nevada's «large colony of Basques», many of these immigrants had «amassed considerable fortunes. They are all law abiding, courteous, intensely religious and - what is most to the point - their aim is not to acquire sufficient money to take them back to the Pyrenees to reside for the balance of their lives, but to build a roof tree and rear their families in the land of their adoption $\gg^{72}$. Accordingly, Basque immigrants were like a new «white» immigrant society in Nevada who provided hard work and made the sheep industry prosper.

In the context of the Great War, Congress reacted to the strong nativist attitudes that had gained momentum in the United States. Between

\footnotetext{
70 Saitua, 2016b, pp. 137-147.

71 Lane, 1977, p. 39.

72 «Desirable Immigrants», Reno Evening Gazette, March 29, 1911, p. 4.
} 
1917 and 1924, Congress adopted measures to restrict immigration from Europe, which disrupted Basque immigration to the United States. In February 1917, before the United States entered WWI, Congress passed an immigration act that established more rigid criteria for admission and strengthened mechanisms for excluding some nationalities. The 1917 Act implemented the following provisions: established a literacy requirement, authorized deportation, enlarged the list of deportable aliens, and increased the categories of Asian exclusion. Although this act did not hinder significantly the increasing recruitment of the Basque immigrant labor, it made more difficult for those Basques already in the country to obtain naturalization. The 1917 immigration act did provide a legal avenue to permit the entrance of immigrant labor. It kept the doors open to «skilled» workers, among others, «if labor of like kind unemployed can not be found in this country». The act mandated the Secretary of Labor to determine «the necessity of importing such skilled labor in any particular instance» ${ }^{73}$. In the near future, when a Basque labor shortage became increasingly acute (particularly in the late 1930s as a consequence of the increasing immigration restrictions in the 1924 Act), this provision served as a legal mechanism to allow the recruitment of more Basque immigrants ${ }^{74}$. The question would be how to demonstrate that Basques were the only «skilled» workers for the open-range sheep industry of the West.

In the war context of 1917 a sheepherder immigrant labor shortage was already apparent. Although the Basque immigrant labor was favorably desired by most sheep owners, it did not meet the expectations of some operators. From Fallon, Nevada, on September 28, William A. Keddie, a prominent Nevada rancher who at that time ran the Williams family outfit, wrote Key Pittman indicating that there was a critical labor shortage in Nevada's sheep industry. Keddie noted that this labor shortage partly was because of some «BASQUE herders we now have and who are becoming entirely too independent to be useful, to say nothing about the growing scarcity of getting them at all». As some Basques quit sheep-

${ }^{73}$ Fitzgerald, 1996, pp. 127-130; Immigration Act of 1917, H.R. 10384, 64th Cong., 2nd Sess., Pub. L. 301, 39 Stat. 874, February 5, 1917, in Statutes of the United States of America, Passed at the Second Session of the Sixty-Fourth Congress, 1916-1917, Part I: Public Acts and Resolutions (Washington, D.C.: Government Printing Office, 1917), pp. 874-898.

74 Saitua, 2016b, pp. 247-248. 
herding jobs and found other better paid employment and became U.S. citizens, Fallon-area ranchers looked for other immigrant groups to recruit dependable labor, particularly Rumanian and Armenian workers. Keddie asked Pittman to find ways in Congress to open the doors for these immigrants, «securing 50 to 200 of these folks, preferably those from a sheep raising country of theirs». Keddie further noted: «Our idea was to get a number of these people, those without families preferred, use them on our ranches until we had accustomed them to our ways etc. and then break them in for work on the ranch and with the sheep» ${ }^{75}$. Keddie's statement exemplifies a determination on the part of ranchers to obtain immigrant sheep herders (young and single from Europe). Pittman also took up the matter with the Department of Labor and the Immigration and Naturalization Service with apparently no qualms about inviting foreign European labor to Nevada ${ }^{76}$. His response was in harmony with the views of ranchers that European labor was preferable to the closer-at-hand Mexican labor for these tasks. He was responding to the needs of his constituency as Nevada's U.S. Senator Patrick McCarran will do decades later in his campaign to import Basque labor during the labor shortage in WWII and af$\operatorname{ter}^{77}$.

Congress increasingly entertained proposals for restrictions on European immigration after World War I. It further tightened immigration rules in 1921 with the Emergency Quota Act that introduced a system of national quotas limiting annual immigration up to three percent of the number of each nationality's inhabitants existing in the United States based on the 1910 census. Because some Basques were in Spain and some in France, their respective populations were included in the quotas for those two countries. Between 1921 and 1924, the total number of immigrants permitted to enter annually under the quota remained the same for both Spain and France: the quota for Spain was set in 912 and for France 5,729 immigrants. In May 1924, Congress passed a new immigration act, the so-called Johnson-Reed Act, which further reduced the quota numbers

75 William A. Keddie to Key Pittman, September 28, 1917, Williams Family Archive, Fallon, Nevada.

${ }^{76}$ Key Pittman to William A. Keddie, October 8, 1917, Williams Family Archive.

77 Saitua, 2016b, pp. 201-215. My dissertation Sagebrush Laborers: Basque Immigrants in Nevada's Sheep Industry, International Dimensions, and the Making of an Agricultural Workforce, 1880-1954 which I defended on April 2016 at the University of Nevada-Reno addresses this question. 
allowing entrance of newcomers. Compared with the previous 1921 legislation, the 1924 Immigration Act was more stringent. The new immigration act reduced the quota number to a two percent based on the 1890 census instead of the 1910 census, which reduced the numbers from eastern and southern European countries ${ }^{78}$.

By looking at the list of quota numbers set for European countries, it is clear how the act of 1924 favored the immigration from northern Europe and largely discriminated against the immigration from southern and eastern Europe. In the case of the Basque Country, the quota number for France was higher than that applied to Spain. In comparison with the French numbers, again, the immigration quota into Spain was sharply limited because they were fewer Spanish immigrants in the United States. The annual quota for Spain was set at 131 and for France at 3,954. From 1924 until the passage of the 1965 immigration act, Basques generally had to find their places within these quota numbers $^{79}$. The provisions systematically reduced the opportunities for those Basques willing to immigrate from the provinces of Biscay, Gipuzkoa, Araba, and Navarre in Spain. In his book Following the Grass, American novelist Harry Sinclair Drago dealt with Basque sheepherders in northern Nevada and referred to the Pyrenees in their home country as «the great Basque barrier» protecting them from the outside world ${ }^{80}$. Of course, on one side of the Pyrenees were the Spanish speaking Basques and on the other side French speakers. For its part, the American immigration quota law created another «Basque barrier» - limiting Spanish Basque immigration more severally than that from the French side of the Pyrenees.

The 1924 act set forth the new American immigrant labor structure in terms of whiteness during the mid-twentieth century. The immigration act of 1924, historian Mae M. Ngai has argued, «differentiated Europeans according to nationality and ranked them in a hierarchy of desirability». Ngai further says that, «Congress and the Quota Board invented national origins that paradoxically upheld both the inviolate nature of racial blood-

78 Ngai, 2004, pp. 21-22; Twelfth Annual Report of the Secretary of Labor. For the Fiscal Year Ended June 1924 (Washington, D.C.: Government Printing Office, 1924), pp. 50-55.

${ }^{79}$ Twelfth Annual Report of the Secretary of Labor. For the Fiscal Year Ended June 1924, pp. 51-55.

80 Drago, 1924, p. 11. 
lines and the amalgamation of the descendents of European nationalities into a single white American race». And if the American whiteness construction was reinforced after the passage of this law, she says, so did the idea of the «backwardness and unassimiability of the nonwhite races» ${ }^{81}$. Between 1924 and 1965, as Matthew F. Jacobson has argued, white immigrants were blended together to form an amorphous group called Caucasians $^{82}$.

At that time, like many other immigrants who left Europe in the late nineteenth and early twentieth centuries, some authors classified Basques as Caucasian, despite the many mysteries surrounding them ${ }^{83}$. In the early 1920s, the Basque meant both «white» and «Caucasian» race in the American society ${ }^{84}$. On February 4, 1928, significantly, the New York Times included Basques in the list of «Caucasians and admitted as such with other aliens defined in the law as "white"». Whiteness enabled Basques to be seen as an increasingly exceptional «industrious» labor. As soon as Basque immigrants were labeled as Caucasians, their desirability in the host society increased. In this sense, American newspapers continued stating that Basques were a distinct and pure race in Europe, and further, a «Caucasian race» ${ }^{85}$.

In the late 1920s, as Basques integrated into the white mainstream, these immigrants encountered increasing difficulties entering the United States. However, the decline in Basque immigration helped accelerate the integration process of the Basque-American community in the West. Thus, ranchers began to face difficulties employing Basque herders: their preferable labor for sheep raising. They held fast to their beliefs and convictions that Basque immigrants had racial traits that made them the backbone of the sheep industry. Because of a growing scarcity of labor, Mexicans replaced Basques as sheepherders ultimately reinforcing whiteness as the norm. The subsequent othering of Mexicans in turn reinforced the notion that Basques represented an exceptional and anomalous racial stock in the scale of being «white», making them a more desirable immigrant. In the eyes of many western sheep owners, the Basque was a co-

\footnotetext{
${ }^{81}$ Ngai, 2004, pp. 24, 37, 25.

82 Jacobson, 1998, pp. 91-96.

${ }^{83}$ Evening Independent, October 20, 1922; Lethbridge Herald, October 20, 1922, p. 4; Des Moines Capital, October 20, 1922, p. 8.

${ }^{84}$ Nevada State Journal, February 12, 1924, p. 4.

85 New York Times, February 4, 1928, p. 26; Davis, 1927, p. 55.
} 
hesive, cheap, and non-unionized labor immigrant group ${ }^{86}$. This last factor is particularly important at a time when workers' unions lost strength in the United States ${ }^{87}$. The preference was for Basques because they were «whiter» than Mexicans with all the cultural baggage that implied-reliable laborers, honesty, dedication to the care of sheep, the chief capital investment of the industry.

\section{Conclusion}

Although the sheepherding practice of Basque immigrants was not different from other groups, their ubiquitous presence at all levels within the sheep industry, from the lowest ranking labor to the high levels of stock outfits, gave this business a foreign character in the eyes of many Americans. During the early twentieth century, as Congress and the President moved to establish forest reserves and eventually National Forests, issues of rangeland governance made the Basque question and itinerant sheepherders central to a political debate at the state and national level over who could use public grazing lands. At the same time, the establishment, consolidation, and development of Basque-owned sheep outfits channeled increasing migration of Basque labor forces and facilitated employment of fellow countrymen. The economic linkages and interaction between the Basque sheep firms and local companies strengthened the position of the Basque workers in the labor pool of the industry. By the early 1910s, although still faced with discrimination and stigmatization on the ranges, it can be said that Basque immigrants were settling and integrating into the broader American society of Nevada and other western states. Taking advantage of all the late nineteenth century racial anthropological studies and literature that made them «different», Basque immigrants moved from being an oppressed and impoverished population to being an honorable class of laborers. Many ranchers and popular public opinion began to recast the Basque laborer in essentialist terms as an ancient white race of Europe already adapted to working in harsh environmental conditions and with a cultural and a heredity disposing them to the care of stock animals. All of which said Basques were racially and cultur-

\footnotetext{
${ }^{86}$ Saitua, 2016b, pp. 164-173, 197-205.

87 Bosch, 1991, pp. 41-42.
} 
ally preadapted to sheep herding. Racializing Basques was a way of setting them a part. It was after the passage of the immigration law of 1924 when Basques were considered «white» by Anglo-Americans. Longtime American ranchers especially created a stereotype of the Basque as a qualified, strong, honorable, dependable, honest, and good laborer. In the eyes of the Anglo ranchers, Basques acquired the label of «skilled» sheep laborers and even the «best sheepherders». This image intermingled with the romanticized Turnerian frontier myth further championing the opportunities of the «free land» frontier for those with the grit and determination to settle it.

The development of «white» attitudes in the conduct of labor relations had a powerful influence over the Basque sheepherders in Nevada and the entire American West. Equating Basques and people of a good European racial type was commonplace among contemporary observers in the popular press. These perceptions prevailed in American public opinion for years. The «unique» and «white racial» identity bestowed to the Basque became a determinant factor for these immigrants' labor relationships within the sheep industry and the larger «racial» environment of the West. By the early twentieth century, although at first they were subjected to overt ethnic and «racial» discrimination, Basque immigrants were soon placed at the top of the «racialized» sheep agricultural labor hierarchy. Since the late nineteenth century, as Basque immigrants resettled in the western states in different historical contexts, through the Anglo-American lenses, they were socially constructed as an ancient, undetermined, unique, and mysterious «white-blood-race» from Europe. The vagueness of the «racial» construction surrounding Basques gave them distinctiveness. Their alleged «racial» difference set them off from some other ethnic groups involved in the sheep grazing occupation of the West. As soon as Basque immigrant workers were categorized as «white subjects», their social desirability increased within the western «racial» frontier. Well into the twentieth century, the «white privilege» served the whole Basque immigrant community to acquire a respected position not only in the labor pool of the sheep industry, but also in the general core-society. In the western race-based socialization, Basque immigrants themselves quickly understood the socio-economic benefits conferred by «whiteness» and further took advantage of being categorized as «white». 


\section{Bibliography}

ALLEN, Theodore W., The Invention of the White Race: The Origin of Racial Oppression in Anglo-America, Verso, London and New York, 1997.

ALMAGUER, Tomás, Racial Fault Lines: The Historical Origins of White Supremacy in California, University of California Press, Berkeley, 1994.

ANGULO MORALES, Alberto and ÁLVAREZ GILA, Óscar (coords.), Las migraciones vascas en perspectiva histórica (siglos $\mathrm{XVI-XX)}$, Universidad del País Vasco, Bilbao, 2002.

AUSTIN, Mary, The Flock, Houghton Mifflin Co., Boston, 1906.

AZCONA MAULEON, Jesús, «La delimitación antropológica y etnológica de lo vasco y de los vascos», Cuadernos de etnología y etnografía de Navarra, 14, 40, 1982, pp. 753-802.

AZCONA PASTOR, José Manuel. Possible Paradises: Basque Emigration to Latin America, University of Nevada Press, Reno, 2004.

BARRERA, Mario, Race and Class in the Southwest: A Theory of Racial Inequality, University of Notre Dame Press, Notre Dame, 1979.

BIETER, John and BIETER, Mark, An Enduring Legacy: The Story of Basques in Idaho, University of Nevada Press, Reno, 2000.

BOGARDUS, Emory S., «A Race-Relations Cycle», American Journal of Sociology, 35, 4, 1930, pp. 612-617.

BOSCH, Aurora, «Estados Unidos en los años treinta: ¿Un socialismo imposible?», Historia Social, 11, 1991, pp. 39-56.

CASTELLI, Joseph R., Basques in the Western United States: A Functional Approach to Determination of Cultural Presence in the Geographic Landscape, Ph.D. dissertation, University of Colorado, 1970.

DAVIS, Eleanor, «The Basques in Malheur County», Commonwealth Review, 9, 2, 1927, pp. 51-55.

DOUGLASS, William A. and BILBAO, Jon, Amerikanuak: Basques in the New World, University of Nevada Press, Reno, 1975.

DOUGLASS, William A., «The Basques of the American West: Preliminary Historical Perspectives», Nevada Historical Society Quarterly, 8, 4, 1970 , pp. 12-25.

DRAGO, Harry Sinclair, Following the Grass, The Macaulay Company, New York, 1924.

ECHEVERRIA, Jeronima, Home Away from Home: A History of Basque Boardinghouses, University of Nevada Press, Reno, 1999.

EDLEFSEN, John B., A Sociological Study of the Basques of Southwest Idaho, Ph.D. dissertation, State College of Washington, 1948.

EMBRY, Jessie L. and CANNON, Brian Q. (eds.), Immigrants in the Far West: Historical Identities and Experiences, University of Utah Press, Salt Lake City, 2015. 
ETULAIN, Richard W. (ed.)., Basques of the Pacific Northwest, Idaho State University Press, Pocatello, 1991.

ETULAIN, Richard W., «The Basques in Western American Literature», in DOUGLASS, William A., ETULAIN, Rirchard W. y JACOBSEN, William H., Jr. (eds.), Anglo-American contributions to Basque studies: essays in honor of Jon Bilbao, Desert Research Institute on the Social Sciences, Reno, 1977, pp. 7-18.

FERGUSON, Niall, Colossus: The Price of America's Empire, Penguin Press, New York, 2004.

FIELDS, Barbara J., «Ideology and Race in American History» in J. Morgan Kousser and James M. McPherson (eds.), Region, Race, and Reconstruction: Essays in Honor of C. Vann Woodward, Oxford University Press, New York, 1982, pp. 143-177.

FITZGERALD, Keith, The Face of the Nation: Immigration, the State, and the National Identity, Stanford University Press, Stanford, 1996.

FOSS, Phillip O., Politics and Grass: The Administration of Grazing on the Public Domain, University of Washington Press, Seattle, 1960.

GAISER, Joseph H., The Basques of the Jordan Valley Area: A Study in Social Processes and Social Change, Ph.D. dissertation, University of Southern California, 1944.

GARATE, Donald T., «Basque Names, Nobility, and Ethnicity on the Spanish Frontier», Colonial Latin American Historical Review, 2, 1, 1993, pp. 77-104.

GARATE, Donald T., «Juan de Oñate's Prueba de Caballero, 1625: A Look at His Ancestral Heritage», Colonial Latin American Historical Review, 7, 2, 1998.

GARATE, Donald T., Juan Bautista de Anza: Basque Explorer in the New World, 1693-1740, University of Nevada Press, Reno, 2005.

GÓMEZ-IBÁÑEZ, Daniel Alexander, The Rise and Decline of Transhumance in the United States, Master's thesis, University of Wisconsin, 1967.

GOODMAN, David, Spanish Naval Power, 1589-1665. Reconstruction and Defeat, Cambridge University Press, Cambridge, 1997.

HARKNESS, Ione B., «Basque Settlement in Oregon», Oregon Historical Quarterly, 34, 3, 1933, pp. 273-275.

HARKNESS, Ione B., Certain Community Settlements in Oregon, Master's thesis, University of Southern California, 1925.

HATFIELD, Kevin D., "We Were Not Tramp Sheepmen»: Resistance and Identity in the Oregon Basque Community, Accustomed Range Rights, and The Taylor Grazing Act, 1890-1955, Ph.D. dissertation, University of Oregon, 2003.

IGNATIEV, Noel, How the Irish Became White, Routledge, New York and London, 1995. 
The Best Sheepherder. The Racial Stereotype of Basque Immigrants...

JACOBSON, Matthew F., Whiteness of a Different Color: European Immigrants and the Alchemy of Race, Harvard University Press, Cambridge, 1998.

JOHNSON, Chalmers, The Sorrows of Empire: Militarism, Secrecy, and the End of the Republic, Metropolitan Books, New York, 2004.

JORDAN, Terry G. and KAUPS, Matti E., The American Backwoods Frontier: An Ethnic and Ecological Interpretation, Johns Hopkins University Press, Baltimore and London, 1989.

JORDAN, Terry G., «Preadaptation and European Colonization in Rural North America», Annals of the Association of American Geographers, 79, 4, 1989, pp. 489-500.

KELLY, James P., The Settlement of Basques in the American West, Senior paper, Harvard University, 1967.

KESSELL, John L., Spain in the Southwest: A Narrative History of Colonial New Mexico, Arizona, Texas and California, University of Oklahoma Press, Norman, 2002.

LANE, Richard H., «Trouble in the Sweet Promised Land: Basques in Early 20th Century Northeastern Nevada», in DOUGLASS, William A., ETULAIN, Rirchard W. y JACOBSEN, William H., Jr. (eds.), Anglo-American contributions to Basque studies: essays in honor of Jon Bilbao, Desert Research Institute on the Social Sciences, Reno, 1977, pp. 33-41.

LHANDE, Pierre, L'Emigration Basque: Histoire, Economie, Psychologie, Nouvelle Librairie Nationale, Paris, 1910.

LUEBKE, Frederick C. (ed.), European Immigrants in the American West: Community Histories, University of New Mexico Press, Albuquerque, 1998.

LUEBKE, Frederick C., Germans in the New World: Essays in the History of Immigration, University of Illinois Press, Chicago, 1990.

MCCALL, Grant E., Basque-Americans and A Sequential Theory of Migration and Adaptation, Master's thesis, San Francisco State College, 1968.

MCCULLOUGH, Flavia M., The Basques in the Northwest, Master's thesis, University of Portland, 1945.

MUIR, John, The Mountains of California, The Century Co., New York, 1894.

NEWTON, Milton, «Cultural Preadaptation and the Upland South», Geoscience and Man, 5, 1974, pp. 143-154.

NGAI, Mae M., Impossible Subjects: Illegal Aliens and the Making of Modern America, Princeton University Press, Princeton, 2004.

OMI, Michael and WINANT, Howard, Racial Formation in the United States: From the 1960s to the 1980s, Routledge and Kegan Paul, New York, 1994.

PAGLIARULO, Carol M., Basques in Stockton: A Study of Assimilation, Master's thesis, College of the Pacific, 1948.

PILDAIN SALAZAR, María Pilar, Ir a América. La emigración vasca a América (Guipúzcoa 1840-1870), Caja de Ahorros Municipal de San Sebastián, San Sebastián, 1984. 
POWERS, Stephen, The American Merino: For Wool and for Mutton, Orange Judd Company, New York, 1907.

RIPLEY, William Z., The Races of Europe: A Sociological Study, D. Appleton and company, New York, 1899.

ROEDIGER, David R., The Wages of Whiteness: Race and the Making of the American Working Class, Verso, London and New York, 1991.

ROOSEVELT, Theodore, The Winning of the West, vol. 1, G. P. Putman's Sons, New York, 1889.

ROWLEY, William D., «Privilege vs. Right: Livestock Grazing in U.S. Government Forests», in Harold K. Steen (ed.), History of Sustained-Yield Forestry: A Symposium, Forest History Society, Durham, 1984, pp. 61-67.

ROWLEY, William D., U.S. Forest Service Grazing and Rangelands: A History, Texas A\&M University Press, College Station, 1985.

RUA, Concepción de la, «Los estudios de Paleoantropología en el País Vasco», Munibe, 42, 1990, pp. 199-219.

RUBIO POBES, Coro, «Centinelas de la Patria. Regionalismo vasco y nacionalización española en el siglo XIX», Historia contemporánea, 53, 2016, pp. 393-425.

RUBIO POBES, Coro, Fueros y constitución: la lucha por el control del poder (País Vasco, 1808-1868), Universidad del País Vasco, Bilbao, 1997.

RUBIO POBES, Coro, La identidad vasca en el siglo XIX: discurso y agentes sociales, Biblioteca Nueva, Madrid, 2003.

RUBIO POBES, Coro, Revolución y tradición: el País Vasco ante la Revolución liberal y la construcción del Estado español (1808-1868), Siglo XXI, Madrid, 1996.

RUIZ, Allura N., The Basques-Sheepmen of the West, Master's thesis, University of Nevada, 1964.

SAITUA, Iker, «Becoming Herders: Basque Immigration, Labor, and Settlement in Nevada, 1880-1910», Montana: The Magazine of Western History, 66, 4, 2016a, pp. 58-70.

SAITUA, Iker, Sagebrush Laborers: Basque Immigrants in Nevada's Sheep Industry, International Dimensions, and the Making of an Agricultural Workforce, 1880-1954, Ph.D. dissertation, University of Nevada-Reno, 2016b.

SATHER, Clifford A., Marriage Patterns Among the Basques of Shoshone, Idaho, Master's thesis, Reed College, 1961.

SAXTON, Alexander, The Indispensable Enemy: Labor and the Anti-Chinese Movement in California, University of California Press, Berkeley and Los Angeles, 1971.

SAXTON, Alexander, The Rise and Fall of the White Republic: Class Politics and Mass Culture in Nineteenth-Century America, Verso, London and New York, 1990. 
The Best Sheepherder. The Racial Stereotype of Basque Immigrants...

SHEPPERSON, Wilbur S., Restless Strangers: Nevada's Immigrants and their Interpreters, University of Nevada Press, Reno, 1970.

SILEN, Sol, La Historia de los Vascongados en el Oeste de los Estados Unidos, Las Novedades, Inc., New York, 1917.

SIMMONS, Marc, The Last Conquistador: Juan de Oñate and the Settling of the Far Southwest, University of Oklahoma Press, Norman, 1991.

SNYDER, James B., «Putting 'Hoofed Locusts' Out to Pasture», Nevada Historical Society Quarterly, 46, 3, 2003, pp. 139-171.

TOWNLEY, John M., Turn This Water Into Gold: The Story of the Newlands Project, Nevada Historical Society, Reno, 1998.

TURNER, Frederick Jackson, «The Winning of the West», The Dial, 10, 1889, pp. 71-73.

TURNER, Frederick Jackson, The Frontier in American History, Henry Holt and Company, New York, 1948.

WEBER, David J., The Spanish Frontier in North America, Yale University Press, New Haven, 1992.

WHITE, Richard, «It's Your Misfortune and None of My Own»: A History of the American West, University of Oklahoma Press, Norman, 1991.

WILCOX, Mary S., A Historical Study of the Basque Race with Special Reference to the United States, Master's thesis, University of Utah, 1939.

YOUNG, James A. and SPARKS, B. Abbott, Cattle in the Cold Desert, Utah State University Press, Logan, 1985.

\section{Funding}

This article has been made possible through a postdoctoral fellowship conferred by the Department of Education, Universities, and Research of the Basque Government.

\section{About the Author}

Iker Saitua received his Ph.D. from University of Nevada, Reno (2016). He holds a B.A. in history from University of the Basque Country (2010) and a M.A. in contemporary history from the same institution. Saitua's primary research interests include western, labor, immigration, and environmental history. His work focuses largely on the intersections between agricultural labor, natural resources, and livestock raising in the American West. He is particularly interested in grazing issues on the western public lands, as well as the nineteenth and twentieth century migration of European immigrant labor forces to North America. Saitua is a specialist in the history of Basque immigration to the United States. 